\title{
Pengaruh penerapan problem based learning terhadap literasi lingkungan siswa SMP pada materi pencemaran lingkungan
}

\section{(The effect of problem based learning application towards junior high school students' environmental literacy on environmental pollution material)}

\author{
Muhamad Nur Siddiq*, Bambang Supriatno, Saefudin \\ Departemen Pendidikan Biologi FPMIPA Universitas Pendidikan Indonesia, Bandung, Indonesia \\ *Corresponding author: muhamadnursiddiq@gmail.com
}

Received: 21 February 2020 - Accepted: 29 March 2020 - Published: 31 March 2020

\begin{abstract}
This study was aimed to investigate the effect of problem based learning to environmental literacy for junior high school in environmental pollution subject. The study of students' environmental literacy covered three aspects, there were knowledge, attitudes, and cognitive skills. The research methods used quasi-experimental and non-equivalent control group design. The sample of this research was seventh grade students in junior high school consisting of 27 experimental class students and 25 control class students. The instruments used in this study were multiple choice questions for aspects of knowledge and cognitive skills with Jatigede Reservoir as an environmental content, Likert scale questionnaires for attitude aspects, observation sheets of problem based learning syntax and student questionnaire in learning problem based learning. Pre test was given to the experimental and control class before learning begun and post test was given to the experimental and control class after the last learning was held. The results showed that the knowledge aspect showed a significant difference which meant that there was an influence from the results of the treatment given, while the aspect of cognitive attitude and skills did not show a significant difference, which meant there was no influence from the results of the treatment given. The achievement of the syntax of problem based learning is in the category of almost all activities. Students' responses to the implementation of problem based learning showed an agreed response.
\end{abstract}

Keywords problem based learning, environmental literacy, environmental pollution

\begin{abstract}
ABSTRAK Penelitian ini dilakukan untuk memberikan gambaran pengaruh problem based learning terhadap literasi lingkungan siswa SMP pada materi pencemaran lingkungan. Literasi lingkungan siswa yang diteliti mencakup tiga aspek yaitu pengetahuan, sikap dan keterampilan kognitif. Metode penelitian yang digunakan pada penelitian ini yaitu quasy experimental dan desain penelitian non equivalen control group design. Sampel penelitian ini adalah siswa kelas VII SMP yang terdiri dari 27 siswa kelas eksperimen dan 25 siswa kelas kontrol. Instrumen yang digunakan dalam penelitian ini yaitu soal pilihan ganda untuk aspek pengetahuan dan keterampilan kognitif dengan konten lingkungan waduk Jatigede, angket skala likert pada untuk aspek sikap, lembar observasi keterlaksanaan sintaks problem based learning dan angket respon siswa terhadap pembelajaran problem based learning. Pre test diberikan pada kelas eksperimen dan kontrol sebelum pembelajaran dimulai serta post test diberikan pada kelas eksperimen dan kontrol sesudah pembelajaran pertemuan terakhir dilaksanakan. Hasil penelitian menunjukkan pada aspek pengetahuan menunjukkan perbedaan signifikan yang berarti terdapat pengaruh dari hasil perlakukan yang diberikan, sedangkan pada aspek sikap dan keterampilan koginitif tidak menunjukkan perbedaan signifikan yang berarti tidak terdapat pengaruh dari hasil perlakukan yang diberikan. Ketercapaian sintaks problem based learning ada pada kategori hampir seluruh kegiatan terlaksana. Respon siswa terhadap pelaksanaan problem based learning menunjukkan respon positif.
\end{abstract}

Kata kunci problem based learning, literasi lingkungan, pencemaran lingkungan

\section{PENDAHULUAN}

Menurut data Badan Pusat Statistik (2018), indeks perilaku ketidakpedulian lingkungan hidup Indonesia tahun 2018 menunjukkan angka 0,51. Angka ini menyatakan bahwa ketidakpedulian cukup tinggi atau kesadaran masih menunjukkan angka rendah. Ketidakpedulian masyarakat terhadap lingkungan dikhawatirkan akan berakibat terhadap kerusakan sumber daya alam, yang pada akhirnya akan menimbulkan bencana alam. Permasalahan kepedulian masyarakat terhadap lingkungan dipengaruhi oleh beberapa faktor. Menurut Yunansah \& Herlambang
(2017) kondisi di masyarakat diperparah dengan rendahnya pemahaman masyarakat perihal hakikat manusia sebagai makhluk multidimensional, hal ini berimbas pada terabaikannya kesadaran manusia akan kewajiban untuk senantiasa menjaga keselarasan dan keharmonisan alam. Besarnya populasi manusia ikut memengaruhi kerusakan lingkungan. Kurangnya literasi lingkungan yang dimiliki masyarakat ikut mendukung tingkat kerusakan lingkungan (Rijal et al., 2018).

Permasalahan lingkungan yang menjadi sorotan dari dampak pembangunan infrastruktur salah satunya di sekitar genangan Waduk Jatigede Kabupaten Sumedang Provinsi 
Jawa Barat. Pasca penggenangan mega proyek infrastruktur ini turut mengubah kondisi lingkungan di daerah genangan dan di daerah sekitar genangan waduk Jatigede. Kondisi perubahan lingkungan ini cukup memberikan banyak dampak terhadap kondisi masyarakat sekitar. Masyarakat harus beradaptasi dengan kondisi lingkungan yang baru, dari yang semula berhadapan dengan ekosistem darat seperti hutan, sawah dan aliran sungai sekarang berubah menjadi ekosistem danau buatan.

Penelitian yang dilaksanakan oleh Nopianti et al. (2018) menyatakan bahwa pasca penggenangan Waduk Jatigede pada tahun 2015, muncul beberapa permasalahan khususnya pada masyarakat terdampak genangan, seperti kesulitan beradaptasi di lingkungan baru, pengetahuan masyarakat yang terbatas, perubahan kondisi, dan terbatasnya mata pencaharian. Mengacu pada beberapa permasalahan tentang literasi lingkungan dan kaitannya dengan perubahan kondisi ekosistem di Waduk Jatigede, menjadi suatu keharusan bahwa kepedulian masyarakat dalam menjaga lingkungan merupakan hal yang harus diperhatikan. Menurut Yunansyah \& Herlambang (2017) berkaitan dengan permasalahan lingkungan perlu adanya sebuah upaya strategis tentang paradigma baru guna menumbuhkan kesadaran lingkungan dan membangun karakter..

Membangun literasi lingkungan pada usia anak-anak dan remaja sangat penting dalam mengatasi permasalahan lingkungan saat ini (Stevenson et al., 2013). Menurut North American Association of Environmental Education (NAAEE) (2001) bahwa pendidikan lingkungan merupakan sebuah proses yang lengkap dan menyeluruh untuk membantu manusia dalam memahami lingkungan dan permasalahannya. Neal (1995) menyatakan bahwa untuk meningkatkan kesadaran siswa terhadap lingkungan maka siswa perlu diberikan motivasi yang menarik, kemudian dibimbing melakukan observasi. Hal ini didukung Amini \& Munandar (2010) yang menyatakan bahwa membekali siswa dengan pengetahuan tentang lingkungan hidup sejak dini sangatlah strategis, hal ini bertujuan agar siswa peduli terhadap lingkungannya. Beberapa alasan yang yang menjadi latar belakang urgensi anak-anak untuk mendapatkan pendidikan literasi lingkungan diantaranya pertama interaksi yang positif dengan lingkungan merupakan hal penting untuk pengembangan kesehatan anak. Kedua, pendidikan literasi lingkungan dapat meningkatkan kemampuan belajar dan kualitas perjalanan hidup. Ketiga, anak akan melihat alam sebagai sumber kekaguman, kegembiraan dan pesona. Keempat, jiwa anak akan diperkaya oleh alam dan anak akan menemukan sumber kepekaan manusia melalui alam (Kurniasih et al., 2015).

Berkaitan dengan pendidikan lingkungan hidup untuk mengantisipasi perubahan lingkungan lebih lanjut di Waduk Jatigede, perlu upaya pencerdasan khususnya melalui jalur pendidikan formal. Jalur pendidikan formal ditempuh dalam wujud pembelajaran di sekolah yang berdasarkan pada kurikulum. Diharapkan dalam pendidikan formal akan meningkatkan kemampuan kognitif, afektif dan psikomotorik. Hal ini sejalan menurut Sanjaya (2008) bahwa sedikit demi sedikit siswa akan berkembang secara utuh pada aspek pengetahuan, sikap dan psikomotorik. Di setiap jenjang pendidikan formal tentunya terdapat muatan materi tentang pendidikan lingkungan hidup. Di jenjang Sekolah Menengah Pertama (SMP), materi pencemaran lingkungan terdapat dalam Kompetensi Dasar 3.8 yaitu Menganalisis terjadinya pencemaran lingkungan dan dampaknya bagi ekosistem (Kemendikbud, 2013). Untuk menghasilkan siswa yang memliki kompetensi yang baik dalam memecahkan masalah, maka diperlukan proses strategi pembelajaran memecahkan masalah (Wena, 2008). Karena menurut Wena (2008) idealnya dalam aktivitas pembelajaran tidak hanya fokus pada upaya mendapatkan pengetahuan, tetapi juga bagaimana mengimplementasikan pengetahuan yang didapat dalam menghadapi situasi baru atau memecahkan masalah-masalah khusus terkait pelajaran yang dipelajari.

Model pembelajaran problem based learning atau pembelajaran berbasis masalah mengajarkan siswa berpikir kritis dalam menanggapi suatu permasalahan dan merumuskan solusi dari permasalahan tersebut. Schaefer (2013) yang menyatakan bahwa problem based learning merupakan model pembelajaran yang bercirikan adanya permasalahan nyata sebagai bagian untuk peserta didik belajar berpikir kritis, memecahkan masalah, dan memperoleh pengetahuan. Dengan demikian, diharapkan melalui pembelajaran problem based learning dapat membawa siswa ke dalam permasalahan dan membelajarkannya agar berpikir kritis dalam memecahkan masalah dan menambah pengetahuan. Hasil penelitian Suwandi et al. (2016) berkesimpulan bahwa open-ended problem based learning berpengaruh terhadap keterampilan memecahkan masalah pada materi keanekaragaman hayati Indonesia. Namun, penelitian yang pernah dilakukan sebagai upaya meningkatkan literasi lingkungan menggunakan model problem based learning masih terbilang terbatas. Hasil penelitian tindakan kelas di sekolah dasar oleh Febriasari \& Supriatna (2017) menyatakan bahwa literasi lingkungan siswa dapat ditingkatkan melalui pembelajaran di kelas dengan menerapkan model problem based learning. Selain itu, penelitian sejenis yang dilakukan oleh di jenjang SMA oleh Utami (2019) menyatakan bahwa problem based learning dapat meningkatan kompetensi keterampilan dan sikap. Oleh karena itu, perlu dilakukan penelitian mengenai pengaruh penerapan model problem based learning yang dilakukan di jenjang SMP khususnya pada materi pencemaran lingkungan dengan harapan dapat meningkatkan literasi lingkungan bagi siswa dapat menjadi salah satu upaya dalam mencegah dan mengatasi permasalahan kerusakan lingkungan.

\section{METODE}

Metode penelitian yang digunakan adalah quasy experimental dan desain penelitian yang digunakan adalah non-equivalent control group design (Creswell, 2003). Gambaran dari desain penelitian yang dilaksanakan disajikan dalam Tabel 1.

Populasi dalam penelitian ini adalah seluruh kemampuan literasi lingkungan siswa SMP kelas VII di sekitar genangan waduk Jatigede. Sampel dalam penelitian ini adalah literasi lingkungan siswa kelas VII yang terjaring melalui penerapan model problem based learning pada kelas 
eksperimen dan discovery learning pada kelas kontrol di sekitar genangan waduk Jatigede. Jumlah siswa dalam kelas eksperimen sebanyak 27 orang dan kelas kontrol sebanyak 25 orang. Kelas VII dipilih karena disesuaikan dengan materi perubahan lingkungan dalam kurikulum mata pelajaran IPA. Teknik sampling yang digunakan adalah cluster sampling. Semua kelas VII SMP tersebut dianggap memiliki peluang yang sama sehingga diharapkan akan menggambarkan literasi lingkungan siswa.

Tabel 1. Desain penelitian

\begin{tabular}{cccc}
\hline Kelas & Post-test & Perlakuan & Pre-test \\
\hline Eksperimen & O1 & $\mathrm{X}$ & O2 \\
Kontrol & O1 & - & O2 \\
\hline
\end{tabular}

Keterangan:

$\mathrm{X} \quad$ : Kelas dengan model pembelajaran problem based learning

: Kelas dengan model pembelajaran discovery learning

O1 : Pre test untuk mengukur literasi lingkungan

O2 : Post test untuk mengukur literasi lingkungan

Instrumen yang digunakan berupa tes literasi lingkungan siswa yang diadaptasi dari MSELS, lembar observasi keterlaksanaan model problem based learning dan angket respon siswa. Instrumen literasi lingkungan terdiri dari 10 butir soal pilihan ganda untuk mengukur aspek pengetahuan, 10 butir soal skala sikap untuk mengukur aspek sikap dan 5 butir soal pilihan ganda untuk mengukur keterampilan kognitif.

Hasil dari pre test dan post test selanjutnya dilakukan penyekoran berdasarkan kunci jawaban pada aspek pengetahuan dan keterampilan kognitif serta berdasarkan analisis skala sikap khusus pada aspek sikap. Langkah selanjutnya yang dilakukan adalah uji statistika menggunakan software SPSS version 16. Pertama dilakukan uji prasyarat yang mencakup uji normalitas dan uji homogenitas. Selanjutnya dilakukan uji komparasi untuk mengetahui perbedaan antara kelas eksperimen dan kelas kontrol. Untuk data parametrik menggunakan uji independent sample $t$ test, sedangkan data non-parametrik menggunakan uji Mann-Whitney U.

\section{HASIL DAN PEMBAHASAN}

Penelitian yang dilakukan baik pada kelas eksperimen maupun kelas kontrol terdiri atas dua pertemuan dengan total masing-masing kelas adalah 5 jam pelajaran $(5 \times 40$ menit). Pada pertemuan pertama dilakukan pre test diawal pembelajaran kemudian dilajutkan pebelajaran sesuai rencana pelaksanaan pembelajaran serta dilakukan post test pada akhir pembelajaran pertemuan kedua. Literasi Lingkungan diukur dengan soal pilihan ganda dan skala sikap yang mengacu pada aspek literasi lingkungan. Tes diujikan pada saat sebelum dan sesudah pelaksanaan pembelajaran baik pada kelas eksperimen dengan model problem based learning maupun pada kelas kontrol dengan model discovery learning. Data yang telah diujikan dianalisis menggunakan uji statistika dan dibahas berdasarkan masing-masing aspek yang terdapat pada literasi lingkungan.
Pengaruh penerapan problem based learning terhadap literasi lingkungan aspek pengetahuan

Data nilai pengetahuan pada pre test dan post test kelas kontrol dan eksperimen disajikan pada Tabel 2.

Tabel 2. Rekapitulasi statistika data literasi lingkungan pada aspek pengetahuan

\begin{tabular}{ccccc}
\hline \multirow{2}{*}{ Tipe Data } & \multicolumn{2}{c}{ Nilai Pre Test } & \multicolumn{2}{c}{ Nilai Post Test } \\
\cline { 2 - 5 } & Kontrol & $\begin{array}{c}\text { Ekspe- } \\
\text { rimen }\end{array}$ & Kontrol & $\begin{array}{c}\text { Ekspe- } \\
\text { rimen }\end{array}$ \\
\hline Jumlah Siswa & 25 & 27 & 25 & 27 \\
Nilai minimal & 10 & 10 & 20 & 30 \\
Nilai maksimal & 80 & 80 & 90 & 90 \\
Rata-rata & 50,80 & 50,37 & 53,20 & 62,96 \\
St. Deviasi & 16,56 & 18,07 & 17,49 & 17,93 \\
& \multicolumn{2}{c}{0,929} & \multicolumn{2}{c}{0,048} \\
Uji beda & (tidak berbeda & (berbeda signifikan) \\
& signifikan) & \multicolumn{3}{c}{}
\end{tabular}

Berdasarkan pada Tabel 2 dapat dilihat bahwa ratarata nilai pre test kelas eksperimen dan kontrol hampir sama. Sedangkan rata-rata nilai post test kelas eksperimen berbeda lebih tinggi dibandingkan rata-rata nilai post test pada kelas kontrol. Hal ini menunjukkan bahwa literasi lingkungan aspek pengetahuan pada kelas eksperimen dan kontrol berbeda signifikan dan penerapan problem based learing berpengaruh dalam meningkatkan literasi lingkungan aspek pengetahuan.

Salah satu tujuan pendidikan lingkungan menurut UNESCO-UNEP (1978) adalah untuk memberikan kesempatan bagi semua orang untuk mendapatkan pengetahuan yang dibutuhkan untuk menyelesaikan masalah lingkungan saat ini dan mencegah masalah baru. Roth (1992) mendefinisikan literasi lingkungan sebagai kemampuan untuk memahami dan menafsirkan yang berhubungan dengan sistem lingkungan dan mengambil tindakan yang tepat untuk mempertahankan, memulihkan, dan meningkatkan sistem melalui pengetahuan, keterampilan dan kesadaran terhadap masalah lingkungan. Jika dikaitkan dengan konteks pendidikan lingkungan hidup, beberapa berpendapat seperti NAAEE (2001) menyatakan bahwa pendidikan lingkungan adalah sebuah proses yang kompherensif untuk membantu manusia memahami lingkungannya dan isu yang terkait. Hal ini didukung pula oleh pernyataan Lieberman \& Hoody (1998) yang menyatakan bahwa pendidikan lingkungan memiliki strategi sebagai memberikan pengalaman belajar hands-on melalui kegiatan berbasis proyek serta mengembangkan pengetahuan, pemahaman, dan apresiasi terhadap lingkungan hidup. Sehingga melalui pendidikan lingkungan bisa dijadikan wadah dalam mengembangkan aspek pengetahuan siswa terkait lingkungan. Taff et al. (2010) menyatakan bahwa pengetahuan lingkungan mempengaruhi sikap yang pada akhirnya akan meningkatkan niat perilaku. Hal ini sejalan dengan penelitian penelitian Pujianti et al. (2018) bahwa ada korelasi antara aspek pengetahuan dan sikap dalam literasi lingkungan, namun tidak dengan keterampilan kognitif.

Kaitan antara model problem based learning terhadap literasi lingkungan di dukung oleh pernyataan Sanjaya (2008) bahwa melalui proses ini menurut sedikit demi 
sedikit siswa akan berkembang secara utuh, baik pada aspek kognitif, afektif dan psikomotorik. Sehingga diharapkan tujuan akhir pembelajaran adalah menghasilkan siswa yang memiliki pengetahuan dan keterampilan dalam memecahkan masalah yang dihadapi kelak di masyarakat. Untuk menghasilkan siswa yang memliki kompetensi yang andal dalam pemecahan masalah, maka diperlukan serangkaian strategi pembelajaran pemecahan masalah (Wena, 2008). Problem based learning secara signifikan lebih efektif daripada pengajaran tradisional untuk melatih praktisi yang kompeten dan terampil dalam jangka panjang dari pengetahuan dan keterampilan yang diperoleh selama pengalaman belajar (Strobel \& Barneveld, 2009).

Penggunaan bahan ajar ikut berpengaruh terhadap peningkatan aspek pengetahuan, hal ini sejalan dengan penelitian yang dilakukan oleh Suryanti et al. (2018) yang dilakukan pada siswa SMP di Bandung menunjukkan bahwa aspek pengetahuan meningkat pada kategori sedang setelah menggunakan bahan ajar sains terintegrasi. Suryanti et al. (2018) juga menegaskan bahwa pembelajaran sains harus lebih ditekankan pada pemberian isu lingkungan atau masalah secara kontekstual untuk mengembangkan kompetensi siswa untuk dapat mengeksplorasi dan memahami lingkungan alam sekitarnya secara ilmiah dan diarahkan untuk menemukan dan melakukan, sehingga dapat membantu siswa untuk mendapatkan pemahaman yang lebih dalam tentang lingkungan sekitar terutama terkait dengan pencemaran lingkungan. Tumisem (2007) mengemukakan bahwa pelaksanaan pendidikan lingkungan di luar sekolah berbasis ekologi perairan melalui kegiatan pramuka di SD mampu meningkatkan aspek pengetahuan. Penelitian Febriasari \& Supriatna (2017) dalam penelitian tindakan kelas di SD menyatakan temuan bahwa aspek pengetahuan dapat ditingkatkan menggunakan model problem based learning.

\section{Pengaruh penerapan problem based learning} terhadap literasi lingkungan aspek sikap

Data nilai sikap pada pre test dan posttest kelas kontrol dan eksperimen disajikan pada Tabel 3 .

Tabel 3. Rekapitulasi statistika data literasi lingkungan pada aspek sikap

\begin{tabular}{ccccc}
\hline \multirow{2}{*}{ Tipe Data } & \multicolumn{2}{c}{ Nilai Pre Test } & \multicolumn{2}{c}{ Nilai Post Test } \\
\cline { 2 - 5 } & Kontrol & $\begin{array}{c}\text { Ekspe- } \\
\text { rimen }\end{array}$ & Kontrol & $\begin{array}{c}\text { Ekspe- } \\
\text { rimen }\end{array}$ \\
\hline Jumlah Siswa & 25 & 27 & 25 & 27 \\
Nilai minimal & 37,5 & 45 & 42,5 & 65 \\
Nilai maksimal & 95 & 90 & 100 & 95 \\
Rata-rata & 77,38 & 75,09 & 78,5 & 81,2 \\
St. Deviasi & 11,93 & 11,69 & 14,7 & 86,02 \\
& \multicolumn{2}{c}{0,402} & \multicolumn{2}{c}{0,416} \\
Uji beda & (tidak berbeda & (tidak berbeda \\
& \multicolumn{2}{c}{ signifikan) } & signifikan) \\
\hline
\end{tabular}

Berdasarkan pada Tabel 3 dapat dilihat bahwa ratarata nilai pre test dan post test kelas eksperimen dan kontrol tidak berbeda signifikan. Hal tersebut menunjukkan bahwa siswa pada kelas eksperimen dan kelas kontrol memiliki kemampuan yang sama pada awal dan akhir pembelajaran tidak berbeda signifikan. Hal ini berbeda dengan hasil penelitian Pujianti et al. (2018) menunjukkan bahwa ada korelasi antara aspek pengetahuan dan sikap dalam literasi lingkungan, namun tidak dengan keterampilan kognitif. Menurut Eggen \& Kauchak (2012) pengetahuan yang tertanam dalam target akan mempengaruhi sikapnya terhadap lingkungan yang akan dimanifestasikan dalam tindakan/perilaku. Dari pernyataan-pernyataan tersebut, tidak sejalan dengan hasil temuan. Namun, berdasarkan temuan justru aspek pengetahuan terdapat perbedaan signifikan tetapi pada aspek sikap tidak berbeda signifikan. Hal ini diduga karena pembentukan sikap membutuhkan waktu yang relatif lama (tidak cukup 5x40 menit).

\section{Pengaruh penerapan problem based learning terhadap literasi lingkungan aspek keterampilan kognitif}

Data nilai keterampilan kognitif pada pre-test dan posttest kelas kontrol dan eksperimen disajikan pada Tabel 4.

Tabel 4. Rekapitulasi statistika data literasi lingkungan aspek keterampilan kognitif

\begin{tabular}{ccccc}
\hline \multirow{2}{*}{ Tipe Data } & \multicolumn{2}{c}{ Nilai Pre Test } & \multicolumn{2}{c}{ Nilai Post Test } \\
\cline { 2 - 5 } & Kontrol & $\begin{array}{c}\text { Ekspe- } \\
\text { rimen }\end{array}$ & Kontrol & $\begin{array}{c}\text { Ekspe- } \\
\text { rimen }\end{array}$ \\
\hline Jumlah Siswa & 25 & 27 & 25 & 27 \\
Nilai minimal & 0 & 0 & 20 & 0 \\
Nilai maksimal & 100 & 80 & 100 & 100 \\
Rata-rata & 40,8 & 29,62 & 40,8 & 43,7 \\
St. Deviasi & 24,81 & 23,77 & 18,69 & 24,82 \\
& \multicolumn{2}{c}{0,129} & \multicolumn{2}{c}{0,683} \\
Uji beda & (tidak berbeda & (tidak berbeda \\
& \multicolumn{2}{c}{ signifikan) } & signifikan) \\
\hline
\end{tabular}

Berdasarkan pada Tabel 4 dapat dilihat bahwa ratarata nilai pre test dan post test kelas eksperimen dan kontrol hampir sama. Dengan demikian, hal ini menandakan bahwa problem based learning tidak berpengaruh terhadap literasi lingkungan pada aspek keterampilan kognitif. Pada temuan ini hampir sejalan dengan penelitian Pujianti et al. (2018) yang menyatakan bahwa aspek keterampilan kognitif di bidang pertanian dan pesisir termasuk kategori rendah. Dugaan rendahnya ketercapaian ini adalah tidak optimalnya dalam pelaksanaan sintaks problem based learning khususnya pada sintaks pertama yang menyebabkan tidak optimal juga pada sintaks-sintaks selanjutnya. Pada sintaks pertama bagian yang tidak teroptimal adalah siswa belum mampu mengidentifikasi masalah yang dibuktikan dengan kemampuan siswa membuat pertanyaan permasalahan. Kekurangan lain adalah ketidaksesuaian soal instrumen penelitian yang digunakan. Soal yang digunakan kurang memuat soal yang menguji siswa dalam mengidentifikasi permasalahan.

\section{Ketuntasan belajar siswa setelah diterapkan model problem based learning di kelas eksperimen}

Hasil temuan pada data statistika deskriptif terkait rata-rata skor yang direpoleh siswa berbeda-beda pada setiap aspek. Jika dikaikan dengan kriteria ketuntasan minimal yang ditetapkan oleh sekolah sebesar 75 tentunya belum semua aspek melampaui kriteria ketuntasan minimal. Berdasarkan hasil analisis sebelumnya terhadap 
ketercapaian setiap indikator secara rata-rata belum semua indikator tercapai. Ketercapaian setiap indikator hanya baru tercapai pada aspek sikap kelas eksperimen. Adapun hasil rata-rata dari aspek pengetahuan, sikap, dan keterampilan kognitif beserta ketuntasannya terhadap kriteria ketuntasan minimum dan kategorisasi penilaian menurut Arikunto (2013) disajikan dalam Tabel 5.

Tabel 5. Ketuntasan belajar setiap aspek literasi lingkungan pada kelas eksperimen

\begin{tabular}{cccc}
\hline $\begin{array}{c}\text { Aspek Literasi } \\
\text { Lingkungan }\end{array}$ & $\begin{array}{c}\text { Rata- } \\
\text { rata Post } \\
\text { test }\end{array}$ & KKM & Kategori \\
\hline Pengetahuan & 62,96 & Tidak Tuntas & Cukup \\
Sikap & 81,2 & Tuntas & Baik \\
Keterampilan & 43,7 & Tidak Tuntas & Kurang \\
Kognitif & 62,62 & Tidak Tuntas & Cukup \\
\hline Rata-rata & & &
\end{tabular}

Littledyke (2006) menyatakan bahwa untuk membuat siswa memiliki literasi lingkungan merupakan proses yang panjang dan tidak bisa dilakukan secara instan. Dugaan lain yang menjadi kekurangan adalah pemahaman untuk memahami konsep yang diperlukan untuk menyelesaikan masalah masih kurang. Hal ini sesuai dengan pernyataan Sanjaya (2009) bahwa salah satu kelemahan dari problem based learning bahwa jika sebagian anggapan siswa tanpa pemahaman materi yang diperlukan untuk menyelesaikan masalah yang sedang dipelajari, maka mereka akan belajar apa yang mereka ingin pelajari saja.

\section{Keterlaksanaan model problem based learning di kelas eksperimen}

Hasil temuan sebelumnya yang telah memaparkan bahwa problem based learning hanya berpengaruh terhadap aspek pengetahuan saja, tidak pada aspek sikap dan keterampilan kognitif. Temuan tersebut kemudian dianalisis kembali melalui ketercapaian model pembelajaran problem based learning yang diterapkan di kelas eksperimen. Lembar observasi keterlaksanaan model problem based learning diisi oleh seorang observer dari awal pembelajaran hingga akhir pembelajaran. Berikut hasil observasi keterlaksanaan model problem based learning disajikan dalam Tabel 6.

Tabel 6. Hasil observasi keterlaksanaan model problem based learning

\begin{tabular}{clc}
\hline No. & \multicolumn{1}{c}{ Sintaks } & Skor \\
\hline 1 & Memberikan orientasi permasalahan pada siswa & 88,9 \\
\hline 2 & Mengorganisasi Siswa untuk belajar & 50 \\
\hline 3 & $\begin{array}{l}\text { Membimbing penyelidikan siswa secara mandiri } \\
\text { maupun kelompok }\end{array}$ & 100 \\
\hline 4 & Mengembangkan dan menyajikan hasil karya & 100 \\
\hline 5 & $\begin{array}{l}\text { Menganalisis dan mengevaluasi proses } \\
\text { pemecahan masalah }\end{array}$ & 100 \\
\hline \multicolumn{2}{l}{ Persentase Keterlaksanaan } & 92 \\
\hline
\end{tabular}

Berdasarkan Tabel 6 didapatkan persentase keterlaksanaan model problem based learning sebesar $92 \%$ dengan interpretasi menurut Riduwan (2012) yaitu hampir seluruh kegiatan terlaksana. Bagian yang tidak terlaksana terdapat dalam sintaks pertama yaitu memberikan orientasi permasalahan pada siswa khususnya pada kegiatan guru memberikan kesempatan kepada perwakilan siswa untuk mengemukakan pentanyaan yang telah dibuat dan memberikan kesempatan kepada siswa lain untuk menanggapi. Pada kejadian ini, otomatis tidak terjadi diskusi antar siswa dalam memberikan tanggapan terhadap pertanyaan yang telah disusun, melainkan dilanjutkan pada langkah selanjutnya. Dampak terlewatnya langkah ini adalah siswa tidak ada kesempatan dalam belajar mengindetifikasi masalah yang merupakan indikator keterampailan kognitif.

Bagian yang tidak terlaksana selanjutnya sintaks kedua yaitu mengorganisasi siswa untuk belajar khususnya pada kegiatan membagi siswa ke dalam beberapa kelompok heterogen.. Berdasarkan bagian kegiatan pembelajaran yang terlewat ini, diduga menjadikan diskusi baik di dalam kelompok maupun kelas menjadi kurang dinamis. Kegiatan diskusi untuk saling menanggapi pertanyaan yang telah disusun serta kelompok yang memungkinkan homogen cenderung dapat memengaruhi literasi lingkungan.

\section{Respon siswa terhadap pembelajaran dengan menggunakan model problem based learning}

Temuan selanjutnya adalah analisis hasil respon siswa terhadap pembelajaran dengan menggunakan model problem based learning. Penerapan model pembelajaran problem based learning diterapkan pada materi pencemaran lingkungan. Hasil rata-rata respon siswa terhadap pembelajaran dengan menggunakan model problem based learning di setiap indikator pernyataan disajikan pada Tabel 7 berikut.

Tabel 7. Hasil angket respon siswa terhadap pembelajaran menggunakan model problem based learning

\begin{tabular}{clcc}
\hline No. & \multicolumn{1}{c}{ Indikator } & Skor & Kategori \\
\hline 1 & $\begin{array}{l}\text { Ketertarikan siswa terhadap } \\
\text { literasi lingkungan melalui model } \\
\text { pembelajaran berbasis masalah }\end{array}$ & 3,04 & Setuju \\
$2 \quad \begin{array}{l}\text { Ketertarikan siswa tentang } \\
\text { pembelajaran pencemaran }\end{array}$ & 3,15 & Setuju \\
& $\begin{array}{l}\text { lingkungan melalui model } \\
\text { pembelajaran berbasis masalah }\end{array}$ & & \\
3 & $\begin{array}{l}\text { Ketertarikan siswa tentang } \\
\text { aktivitas pembelajaran dengan } \\
\text { model pembelajaran berbasis } \\
\text { masalah }\end{array}$ & Setuju \\
Ketertarikan siswa tentang \\
pelaksanaan pembelajaran IPA \\
dengan penerapan model \\
pembelajaran berbasis masalah
\end{tabular}

Berdasarkan Tabel 7, didapatkan bahwa hasil respon siswa setiap indikator pernyataan menunjukkan kategori setuju. Berdasarkan hasil tersebut, dapat dinyatakan bahwa seluruh siswa pada kelas eksperimen tertarik terhadap pembelajaran dengan menggunakan model problem based learning yang telah dilaksanakan. Secara keseluruhan respon siswa terhadap penerapan model problem based learning ialah positif. Hal ini sejalan dengan pendapat menurut Belt (2001) menyatakan bahwa problem based learning merupakan model pembelajaran yang efektif dan menyenangkan. 
Berdasarkan temuan tentang pengaruh problem based learning terhadap literasi lingkungan khususnya pada aspek pengetahuan dapat dinyatakan bahwa ketertarikan siswa atau kenyamanan siswa dalam pembelajaran ikut memengaruhi pula terhadap peningkatan aspek pengetahuan siswa.

\section{SIMPULAN}

Penerapan problem based learning berpengaruh terhadap peningkatan literasi lingkungan pada aspek pengetahuan, tetapi tidak berpengaruh pada aspek sikap dan keterampilan kognitif.

\section{REFERENSI}

Amini, R. \& Munandar, A. (2010). Pengaruh model pembelajaran pendidikan lingkungan berbasis. Jurnal Penelitian Pendidikan, 11(1), 14-21.

Arikunto, S. (2013). Dasar-dasar evaluasi pendidikan (edisi 2). Jakarta: PT Bumi Aksara.

Badan Pusat Statistik. (2018). Laporan indeks perilaku ketidakpedulian lingkungan bidup Indonesia 2018. Jakarta: Badan Pusat Statistik.

Belt, S. (2001). Problem based learning (PBL) - A case study from environmental sciences. Planet, 4(1), 1718.

Creswell, J. W. (2003). Research design: Qualitative, quantitative, and mixed methods approaches (2nd ed.). Thousand Oaks, CA: Sage.

Eggen, P., \& Kauchak, D. (2012). Strategi dan model pembelajaran mengajarkan konten dan keterampilan berpikir. Jakarta: Indeks.

Febriasari, L. K. \& Supriatna, N. (2017). Enhance environmental literacy through problem based learning. Journal of Physics: Conference Series, 895(1).

Kemendikbud. (2013). Kompetensi Dasar: sekolah menengah pertama (SMP)/madrasah tsanawiyah (MTs). Jakarta: Kemendikbud.

Kurniasih, N., Komariah, N., Rachmawati, T. S., \& Rodiah, S. (2015). Pendidikan literasi lingkungan sebagai penunjang desa wisata agro kecamatan Padaherang Kabupaten Pangandaran. Jurnal Aplikasi Ipteks untuk. Masyarakat, 4(1), 18-21.

Lieberman, G. A., \& Hoody, L. L. (1998). Closing the achievement gap. using the environment as an integrating context for learning. San Diego: State Edducation and Environment Roundtable.

Littledyke. (2006). Science education for environmental awareness: approaches to integrating cognitive and affective domains in: Evangelos I Manolas (editor). Proceedings of the 2006 Naxos International Conference on Sustainable Management and Development of Mountanious and Island Areas (Thace: Media University of Crete), 254 268.

NAAEE. (2001). Using Environment-Based Education to Advance Learning Skills and Character Development. A Report, Annotated Bibliography, and Research. Washington DC: NEETF.

Neal, L. H. O. (1995). Using wetlands to teach ecology \& environmental awareness in general biology. The
American Biology Teacher, 57(3), 135-139.

Nopianti, R., Melinda, T., \& Harahap, J. (2018). Strategi adaptasi masyarakat terdampak pembangunan waduk Jatigede di Dusun Cipondoh Desa Pawenang Kecamatan Jatinunggal Kabupaten Sumedang. Patanjala: Jurnal Penelitian Sejarab dan Budaya, 10, 1734.

Pujianti, N., Munandar, A., \& Surakusumah, W. (2018). Environmental literacy in agriculture and coastal areas. Journal of Physics: Conference Series, 1013, 1-4.

Riduwan. (2012). Metode \&o teknik menyusun proposal penelitian. Bandung: Alfabeta.

Rijal, M., Saefudin, \& Amprasto. (2018). Field trip method as an effort to reveal student environmental literacy on biodiversity issue and context. Journal of Physics: Conf. Series, 1013.

Roth, C. E. (1992). Document resume ed 348 235. Columbus: Eric Digest.

Sanjaya, W. (2008). Perencanaan \& Desain Sistem Pembelajaran. Jakarta: Kencana Prenadamedia Group.

Sanjaya, W. (2009). Strategi Pembelajaran Berorientasi Standar Proses Pendidikan. Jakarta: Prenada.

Schaefer, V., \& Gonzales, E. (2013). Using problem-based learning to teach concepts for ecological restoration. Ecological Restoration, 31(4), 412-418.

Stevenson, K. T., Peterson, M. N., Bondell, H. D., Mertig, A. G., \& Moore, S. E. (2013). Environmental, institutional, and demographic predictors of environmental literacy among middle school children. PLOS ONE, 8(3), 1-11.

Strobel, J., \& Barneveld, A. van. (2009). When is PBL More Effective? A metasynthesis of metaanalyses comparing $\mathrm{pbl}$ to conventional classrooms. Interdisciplinary Journal of Problem Based Learning, 3(1), 44-58.

Suryanti, D., Sinaga, P., \& Surakusumah, W. (2018). Improvement of students' environmental literacy by using integrated science teaching materials. IOP Conference Series: Materials Science and Engineering, 306(1), 1-9. IOP Publishing.

Suwandi, T., Hasnunidah, N., \& Marpaung, R. R. (2016). Pengaruh pembelajaran berbasis masalah open-ended terhadap peningkatan kemampuan pemecahan masalah oleh siswa. Jurnal Pendidikan Progresif, 6(2), 163-173.

Taff, M. A. M., Aziz, A., Haron, R. N. S. R., Rasyid, N. M., \& Yasim, M. M. (2010). Residential outdoor education and environmental attitudes: an examination in a Malaysian University. Journal of Outdoor Recreation, Education, and Leadership, 2(3), 198216.

Tumisem. (2007). Program pendidikan lingkungan berbasis ekologi perairan sebagai upaya pengembangan literasi lingkungan dan konservasi melalui kepramukaan di Sekolah Dasar. Disertasi. Bandung: UPI.

UNESCO-UNEP. (1978). The tbilisi declaration connect. UNESCO-UNEP Environmental Education Nensletter, 3, 1-8.

Utami, F. (2019). Upaya meningkatkan literasi lingkungan siswa sma melalui pembelajaran berbasis masalah pada materi ekosistem. (Skripsi). Bandung: Universitas Pendidikan 
Indonesia.

Wena, M. (2008). Strategi pembelajaran inovatif kontemporer: Suatu tinjauan konseptual operasional. Jakarta: Bumi Aksara.

Yunansah, H., \& Herlambang, Y. T. (2017). Pendidikan berbasis ekopedagogik dalam menumbuhkan kesadaran ekologis dan mengembangkan karakter siswa sekolah dasar. EduHumaniora | Jurnal Pendidikan Dasar Kampus Cibiru, 9(1), 27.

Conflict of Interest Statement: The author(s) declare that the research was conducted in the absence of any commercial or financial relationships that could be construed as a potential conflict of interest.

How to Cite: Siddiq, M.N., Supriatno, B. \& Saefudin. (2020). Pengaruh penerapan problem based learning terhadap literasi lingkungan siswa SMP pada materi pencemaran lingkungan. Assimilation: Indonesian Journal of Biology Education, 3(1), 18-24. 